\title{
Effect of the number of passages of fetal and adult fibroblasts on nuclear remodelling and first embryonic division in reconstructed horse oocytes after nuclear transfer
}

\author{
Xihe $\mathrm{Li}^{1}$, J. L. Tremoleda ${ }^{2}$ and W. R. Allen ${ }^{1 *}$ \\ ${ }^{1}$ University of Cambridge, Department of Clinical Veterinary Medicine Equine Fertility Unit, \\ Mertoun Paddocks, Woodditton Road, Newmarket, Suffolk CB8 9BH, UK; and ${ }^{2}$ Utrecht \\ University, Faculty of Veterinary Medicine, Department of Equine Sciences, Yalelaan 12, \\ 3584 CM Utrecht, The Netherlands
}

The effects of repeated passage in vitro of fetal fibroblast cells (FFC) and adult fibroblast cells (AFC) on nuclear remodelling and first embryonic division when used to reconstruct horse oocytes, and the reasons for the developmental block in progression to the two-cell stage were investigated. A total of 463 metaphase II oocytes produced 427 fibroblast-cytoplasm couplets after nuclear transfer, which finally resulted in 319 reconstructed oocytes. With increasing numbers of passages, the rates of nuclear remodelling decreased in both types of donor cell; about half of the fused donor cell nuclei showed the S-G2prometaphase stages of the first embryonic division 18$20 \mathrm{~h}$ after cell-fusion treatment, irrespective of the number of donor cell passages (FFC: $49 \%$; AFC: $53 \%$ ). The rates of first embryonic division in the reconstructed oocytes fell with increasing age of the donor cells (FFC: $32 \%-26 \%$ $-23 \%$; AFC: $27 \%-23 \%-24 \%$ ) and these rates were significantly lower than those obtained from metaphase II oocytes activated parthenogenetically $(79 \%, P<0.05)$. Microscopic analysis of the organization of the first embryonic division in the developmentally blocked oocytes reconstructed with either FFC or AFC showed that most of these (FFC: $78 \%$; AFC: $92 \%$ ) could not form the mitotic spindle and the metaphase plate of chromosomes. These findings indicate that either fetal or adult fibroblasts that have undergone relatively few passages in vitro are most suitable as donors. However, both types of cell have lower potential to restart first embryonic development after nuclear transfer than do the equivalent cells in other species. Improvement in the rate of donor cell nuclear progression from S-G2-prometaphase to beyond the metaphase stage, and the normal organization of first embryonic development in reconstructed horse oocytes, would seem to be the key to the production of cloned embryos in this species.

\section{Introduction}

Many factors influence the production of cloned animals when using the technique of nuclear transfer. One is the remodelling of the donor cell nucleus within the cytoplasm of the recipient oocyte to organize the first embryonic division. Usually, greater extents of donor cell nuclear remodelling and embryonic development can be achieved when transferring embryonic rather than somatic cell nuclei into the cytoplasm of metaphase II oocytes, although this general rule does not hold true for all species (Campbell et al., 1996a; Kato et al., 2000; Westhusin et al., 2001). The number of donor cell passages is another significant factor in cloning by nuclear transfer. Most reports of successful cloning in domestic animal species have used cells of limited

*Correspondence

Fax: +44 (0)1638 667207; email: vetart@aht.org.uk passage (3-9) as sources of donor nuclei (Wilmut et al., 1997; Kato et al., 1998; Wells et al., 1999; Hill et al., 2000; Reggio et al., 2001). Roh et al. (2000) reported that nuclei from both early passage (8-16) and late passage (17-32) donor cells were capable of supporting in vitro development after nuclear transfer in cattle, although the rate of blastocyst formation was lower when using the late passage cells. Studies of nuclear transfer in the horse are presently in their infancy (Hinrichs et al., 2000; Li et al., 2000a, 2001a; Reggio et al., 2000) and it is necessary to investigate the differences that both the type and the number of in vitro passages of the donor cells make on the whole process.

The present study used both fetal and adult fibroblasts as donor cells for nuclear transfer. The effect of the number of cell passages on nuclear remodelling, and the potential of the reconstructed oocytes to progress to the first embryonic division were investigated, together with attempts to trace the developmental block in progression to the two-cell stage. 


\section{Materials and Methods}

\section{Culture media}

TCM-199 (Gibco BRL, Grand Island, NY) was used as the basic medium for oocyte maturation and culture of the reconstructed oocytes after nuclear transfer. A monolayer of horse oviduct epithelial cells (OEC) was also used in co-culture with the oocytes during maturation and development. TCM-199 was supplemented with $20 \%$ $(\mathrm{v} / \mathrm{v})$ heat-inactivated FBS (Gibco BRL), $10 \mu \mathrm{g} \mathrm{FSH} \mathrm{ml}{ }^{-1}$

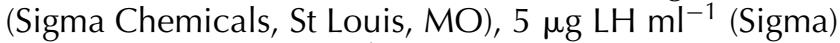
and $1 \mu \mathrm{g}$ oestradiol $\mathrm{ml}^{-1}$ (Sigma) for oocyte maturation.

Culture drops $(500 \mu \mathrm{l})$ containing 20-30 cumulusoocyte complexes (COCs) were made under mineral oil (Sigma) on the monolayer of OEC in a four-well Petri culture plate (Nunc, Roskilde). Groups of 5-10 reconstructed oocytes were cultured in $500 \mu$ l drops of TCM medium on the monolayer of OEC in a four-well Petri culture plate, for development.

\section{Oocyte collection and maturation culture}

Horse ovaries were obtained from a commercial abattoir and transported to the laboratory within $20 \mathrm{~h}$ in PBS containing $1 \mu \mathrm{g}$ gentamicin $\mathrm{ml}^{-1}$ (Gibco BRL) and maintained at a temperature of $10-20^{\circ} \mathrm{C}$. COCs were recovered from the ovaries by scraping the walls of follicles of $0.5-3.0 \mathrm{~cm}$ diameter. Groups of 20-30 COCs were matured in vitro by co-culture with OEC for 28-30 h at $38^{\circ} \mathrm{C}$ in an atmosphere of $5 \% \mathrm{CO}_{2}$ in air ( $\mathrm{Li}$ et al., 2000b, 2001b).

\section{Preparation of donor cells}

Fetal fibroblast cells (FFC) were derived from a 32-dayold Thoroughbred $\times$ Pony fetus and adult skin fibroblast cells (AFC) were obtained from subdermal biopsies recovered from a 4-year-old Pony mare. Doubling of the population of cultured cells progressed to full confluence in four-well Petri culture plates at which time the cells were sub-passaged. After 2-3 sub-passages, cultured cells of both the FFC and AFC lines were frozen in Dulbecco's modified Eagle's medium (DMEM; Gibco BRL) containing 10\% FBS and 10\% dimethyl sulphoxide. The FFC and AFC were thawed and then cultured in DMEM with $10 \%$ FBS for totals of, respectively, 3-5, 6-10 and 11-15 passages. Analysis of the cells by flow cytometry showed that the nuclei of $93.3 \%$ of FFC and $93.6 \%$ of AFC were at the G0-G1 phase of the cycle after starvation culture for 3-5 days in DMEM containing $0.5 \%(\mathrm{v} / \mathrm{v})$ FBS.

\section{Nuclear transfer}

The nuclear transfer procedure ( $\mathrm{Li}$ et al., 2002) was performed using a Transferman micromanipulator (Eppendorf, Hamburg) attached to an inverted microscope (Olympus IMT-2, Tokyo). All the manipulations were performed in a basic medium of Earle's balanced salt solution (EBSS; Gibco BRL) and 20\% (v/v) FBS on a heated stage (CO 102; Linkam, Tadworth) that provided a working temperature of $30^{\circ} \mathrm{C}$.

After 28-30 h maturation in vitro, metaphase II (MII) oocytes were selected after removal of their cumulus cells by treatment in 200 i.u. hyaluronidase $\mathrm{ml}^{-1}$ (Sigma) in EBSS-20\% (v/v) FBS for 5 min followed by gentle pipetting. The MII oocytes were placed for $10 \mathrm{~min}$ in EBSS $-20 \%(\mathrm{v} / \mathrm{v})$ FBS containing $5 \mu \mathrm{g}$ cytochalasin B ml $\mathrm{m}^{-1}$ (CCB; Sigma) and $5 \mu \mathrm{g}$ Hoechst $33342 \mathrm{ml}^{-1}$ (Sigma) before they were enucleated. Oocytes were enucleated in EBSS-20\% (v/v) FBS with $5 \mu \mathrm{g} \mathrm{m}^{-1} \mathrm{CCB}$ and only those oocytes in which removal of both the polar body and the metaphase II nucleus was confirmed by observation under UV light for 3-5 s were included in the study. For donor cells, FFC or AFC were held in EBSS supplemented with $20 \%(\mathrm{v} / \mathrm{v})$ FBS for 1 or $2 \mathrm{~h}$ before a cell of 15-20 $\mu \mathrm{m}$ in diameter was selected and injected into the perivitelline space of the recipient enucleated oocyte, in combination with a small volume (two or three times the volume of the oocyte) of inactivated Sendai virus (VR-907, 1-3 × $103 \mathrm{U} \mathrm{ml}^{-1}$; LGC, Teddington).

\section{Cell fusion and activation of the reconstructed oocytes}

The fibroblast-cytoplasm couplets were aligned manually in $0.28 \mathrm{mmol}$ mannitol fusion buffer $\mathrm{I}^{-1}$ in a $1.0 \mathrm{~mm}$ fusion chamber and subjected to two DC pulses, each of 220-250 kv cm${ }^{-1}$ for $30 \mu \mathrm{s}$ and delivered by an ECM830 Electro Square Porator (BTX, San Diego, CA). Couplets that had fused successfully were then activated chemically by immersing them in PBS containing $5 \mu \mathrm{mol}$ ionomycin $\mathrm{I}^{-1}$ for $5 \mathrm{~min}$, followed by culture for $4 \mathrm{~h}$ in TCM-199 medium containing $10 \mu \mathrm{g} \mathrm{m}^{-1}$ cycloheximide (Sigma). Metaphase II oocytes in the control group were induced to develop parthenogenetically using the same conditions applied to activate the reconstructed oocytes.

Nuclear analysis and development of the reconstructed oocytes to the two-cell stage

Groups of 5-10 reconstructed oocytes were cocultured on the monolayer of OEC in $500 \mu \mathrm{l}$ drops of development medium at $38^{\circ} \mathrm{C}$ in an atmosphere of $5 \%$ $\mathrm{CO}_{2}$ in air. Nuclear remodelling was considered to have occurred when the nucleus had enlarged to two to five times the size of that in the original donor cell, or when the condensed chromatin had become organized in the chromosomes to prometaphase, metaphase and then to beyond metaphase stage of the first embryonic division. Nuclear remodelling was analysed in 121 fused oocytes at $18-20 \mathrm{~h}$ after cell-fusion treatment by staining with $1 \%$ $(\mathrm{w} / \mathrm{v})$ aceto-orcein (Li et al., 2002). Development of the reconstructed oocytes to the two-cell stage was assessed 
Table 1. Influence of the number of donor cell passages on nuclear remodelling 18-20 h after cell fusion using fetal and adult fibroblasts to reconstruct enucleated horse oocytes

\begin{tabular}{|c|c|c|c|c|c|}
\hline \multicolumn{2}{|c|}{ Donor cell } & \multirow[b]{2}{*}{ Total/fused (\%) of oocytes } & \multicolumn{3}{|c|}{ Cell stage of donor nuclear chromatin (\% fused oocytes) } \\
\hline Type & Passages & & G0-G1 & S-G2-prometaphase & $\geqslant$ Metaphase \\
\hline \multirow[t]{4}{*}{ FFC } & $3-5$ & 20/16 (80) & $3\left(19^{a}\right)$ & $9(56)$ & $4\left(25^{\mathrm{a}}\right)$ \\
\hline & $6-10$ & $28 / 23(82)$ & $6\left(26^{\mathrm{a}, \mathrm{b}}\right)$ & $12(52)$ & $5\left(21^{\mathrm{a}}\right)$ \\
\hline & $11-15$ & $30 / 22(73)$ & $8\left(36^{\mathrm{b}}\right)$ & $9(41)$ & $5\left(23^{a}\right)$ \\
\hline & Total & $78 / 61(78)$ & $17(28)$ & $30(49)$ & $14(23)$ \\
\hline \multirow[t]{4}{*}{ AFC } & $3-5$ & $32 / 22(69)$ & $4\left(18^{\mathrm{a}}\right)$ & $12(55)$ & $6\left(27^{\mathrm{a}}\right)$ \\
\hline & $6-10$ & $26 / 19(73)$ & $5\left(26^{a}\right)$ & $8(42)$ & $6\left(32^{a}\right)$ \\
\hline & $11-15$ & 28/19 (68) & $4\left(21^{\mathrm{a}}\right)$ & $12(63)$ & $3\left(16^{\mathrm{a}}\right)$ \\
\hline & Total & $86 / 60(70)$ & $13(22)$ & $32(53)$ & $15(25)$ \\
\hline
\end{tabular}

G0-G1: nuclear size was similar to the original $(15-20 \mu \mathrm{m})$ and showed condensed chromatin.

S-G2-prometaphase: nuclear size expanded to 40-60 $\mu \mathrm{m}$ and the chromatin was homogenized within a nuclear envelope.

$\geqslant$ Metaphase: metaphase and beyond. Nuclear envelope broken down and the chromosomes arranged on the metaphase plate, or separating towards the two poles of the spindle.

FFC: fetal fibroblast cells.

AFC: adult fibroblast cells.

a,b Values with different superscripts within a column are significantly different $(P<0.05)$.

after a further $10-12 \mathrm{~h}$ in culture, thus, $28-30 \mathrm{~h}$ after cell fusion and treatment with cycloheximide.

\section{Analysis of chromatin, microtubules and microfilaments in the reconstructed oocytes at the first embryonic division block}

Reconstructed oocytes from both FFC and AFC that had blocked at the first embryonic division 28-30 h after cell fusion were selected for assessment of cytoskeletal and chromatin structures (Tremoleda et al., 2001). Briefly, the oocytes were initially permeabilized by immersing them for $1 \mathrm{~h}$ at $38^{\circ} \mathrm{C}$ in $\mathrm{M}$ medium (Simerly and Schatten, 1993), and then fixed for $30 \mathrm{~min}$ in $2.5 \%$ paraformaldehyde in PBS. The microtubules were then labelled, first by incubating the fixed oocytes for 90 min at $37^{\circ} \mathrm{C}$ in a $1: 250$ dilution of a monoclonal anti$\alpha$-tublin antibody (Sigma), and then by incubating for $1 \mathrm{~h}$ in a blocking solution (Albertini et al., 1984). Next, the oocytes were exposed to a goat anti-mouse antibody for $1 \mathrm{~h}$ at $37^{\circ} \mathrm{C}$, conjugated to tetramethylrhodamine isothiocyanate (TRITC) and diluted 1:250 in PBS containing $0.5 \%$ Triton X-100 and $0.5 \%$ BSA. The oocytes were then incubated for $1 \mathrm{~h}$ in Alexa Fluor 488 phalloidin (15 i.u. $\mathrm{ml}^{-1}$; Molecular Probes Inc., Eugene, OR) to demonstrate the microfilaments. Finally, the oocytes were washed twice in PBS containing $0.1 \%$ BSA before they were incubated in $\mathrm{TO}^{-\mathrm{PRO}_{3}}\left(1 \mu \mathrm{mol} \mathrm{I}{ }^{-1}\right.$ in PBS; Molecular Probes) for $15 \mathrm{~min}$ to enable visualization of the DNA. The stained oocytes were then mounted under a coverslip with antifade (Vectashield; Vector, Burlingam, CA) and analysed by a confocal laser scanning microscope (Leica TCS MP, Heidelberg) that was mounted on an inverted microscope (Leica DM IRBE) equipped with a kryptonargon ion laser to excite fluorescence for microtubules (TRITC), microfilaments (Alexa Fluor 488) and DNA (TO-
$\mathrm{PRO}_{3}$ ), simultaneously. After treatment, the chromatin was highlighted in blue, the microtubules in red and the microfilaments in green.

\section{Statistical analysis}

Each experimental group comprised 3-5 replicates and the results were evaluated by chi-squared analysis. Differences between groups were considered statistically significant when $P<0.05$.

\section{Results}

\section{Nuclear remodelling of FFC and AFC}

A total of 463 MIl oocytes produced 427 fibroblastcytoplasm couplets after nuclear transfer, which resulted in 319 reconstructed oocytes. The rates of nuclear remodelling $18-20 \mathrm{~h}$ after cell fusion when using FFC and AFC as donor cells for oocyte reconstruction are shown (Table 1). Representative stages of the process are illustrated (Fig. 1). The rates of cell fusion between the recipient cytoplast and either FFC or AFC were 73$82 \%$ and $68-73 \%$, respectively. There were no significant differences when using cells that had been passaged 3-5, 6-10 or 11-15 times. Nor were there any differences between FFC and AFC.

When passaging the donor cells, the number of nuclei that showed no change in G0-G1 configuration in the reconstructed oocytes after fusion with FFC increased significantly when using cells that had been passaged 11-15 times compared with those passaged 3-5 times (36\% versus $19 \%, P<0.05)$. However, this was not the case for oocytes fused with AFC. With both types of cell, about half of the fused donor cell nuclei showed 

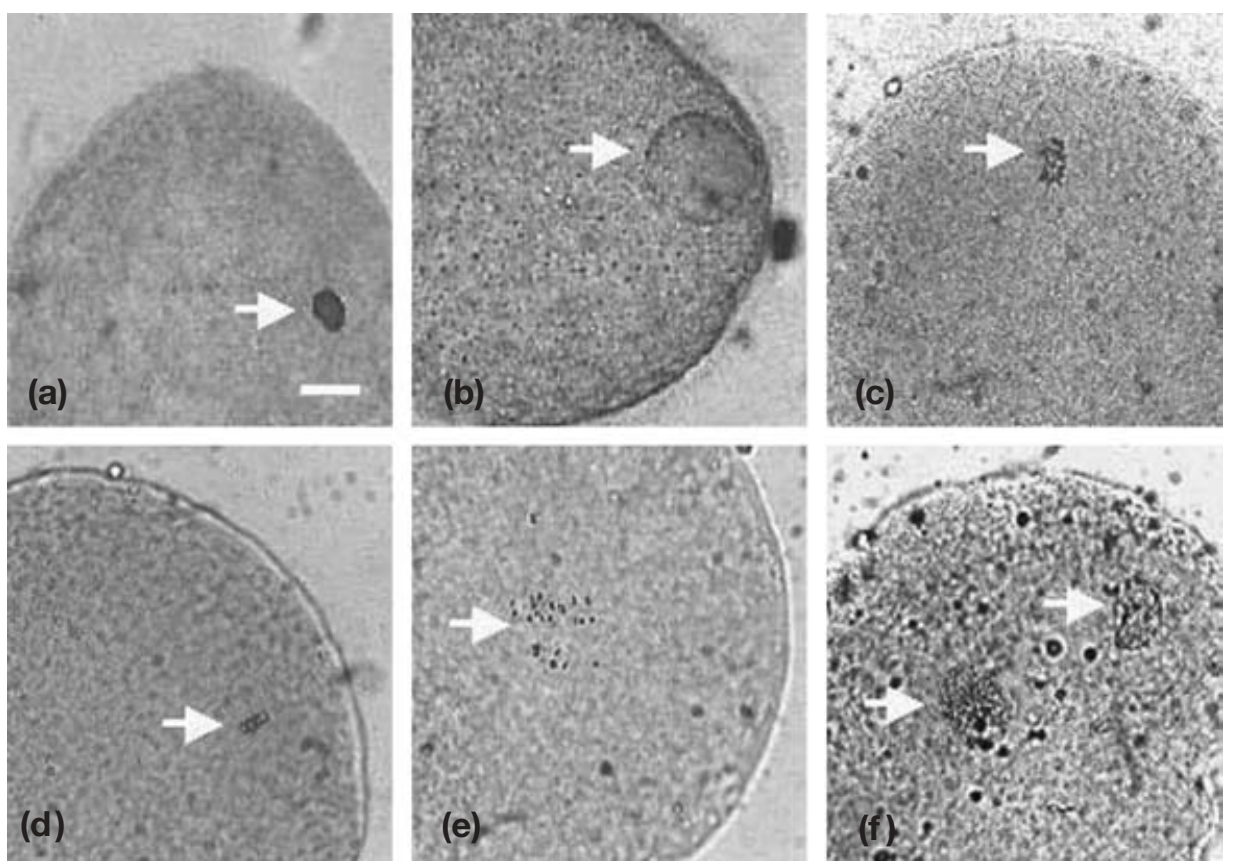

Fig. 1. Donor cell nuclear remodelling in reconstructed horse oocytes $18-20 \mathrm{~h}$ after cell fusion after nuclear transfer. (a) Original donor cells $\left(\mathrm{G}_{0}-\mathrm{G}_{1}\right.$ stage); (b) swelling nucleus; (c) prometaphase stage; (d) metaphase stage; (e) anaphase stage (chromosomes separating); (f) two nuclei. Arrows indicate the position of the chromatin or nucleus. Scale bar represents $20 \mu \mathrm{m}$.

Table 2. Rate of first embryonic division 28-30 h after cell fusion in the nuclei of either fetal or adult fibroblast cells used to reconstruct enucleated horse oocytes

\begin{tabular}{|c|c|c|c|c|c|}
\hline \multicolumn{2}{|c|}{ Donor cell } & \multirow[b]{2}{*}{ Number of fused oocytes } & \multicolumn{3}{|c|}{ Number of two-cell embryos (\% fused oocytes)* } \\
\hline Type & Passages & & Total & Normal & Abnormal \\
\hline Parthenogenetic control & & 24 & $19\left(79^{a}\right)$ & $13(54)$ & $6(25)$ \\
\hline \multirow[t]{4}{*}{ FFC } & $3-5$ & 31 & $10\left(32^{b}\right)$ & 7 & 3 \\
\hline & $6-10$ & 42 & $11\left(26^{b}\right)$ & 8 & 3 \\
\hline & $11-15$ & 30 & $7\left(23^{b}\right)$ & 5 & 2 \\
\hline & Total & 103 & $28(27)$ & $20(19)$ & $8(8)$ \\
\hline \multirow[t]{4}{*}{ AFC } & $3-5$ & 36 & $10\left(27^{b}\right)$ & 7 & 3 \\
\hline & $6-10$ & 30 & $7\left(23^{b}\right)$ & 4 & 3 \\
\hline & $11-15$ & 29 & $7\left(24^{b}\right)$ & 5 & 2 \\
\hline & Total & 95 & $24(25)$ & $16(17)$ & $8(8)$ \\
\hline
\end{tabular}

FFC: fetal fibroblast cells; AFC: adult fibroblast cells.

*Two-cell embryos were evaluated morphologically as normal or abnormal.

${ }^{a, b}$ Values with different superscripts within a column are significantly different $(P<0.05)$.

the S-G2-prometaphase stages of the first cell cycle (FFC: $41-56 \%$; AFC: 42-63\%), irrespective of the number of donor cell passages. On average, only $23 \%$ of FFC and $25 \%$ of AFC progressed to the metaphase stage (or beyond) of the first cell cycle after chemical activation treatment.

\section{Cleavage of the reconstructed oocytes}

After in vitro culture for 28-30 h after cell fusion, the rates of first embryonic division in oocytes reconstructed with both FFC and AFC tended to decline with increasing number of passages of the donor cells (Table 2, FFC: $32 \%-26 \%-23 \%$; AFC: $27 \%-23 \%-24 \%$ ), although not significantly (Table 2). Some abnormal two-cell embryos showing a polynucleus, or a nucleus-free blastomere, or unequal cleavage with some fragments were found after nuclear transfer using both FFC (8\%) and AFC (8\%). In the control group, 19 of $24(79 \%)$ treated metaphase II oocytes developed parthenogenetically to the two-cell stage, a significantly higher proportion than that obtained with the reconstructed oocytes $(P<0.05)$. 

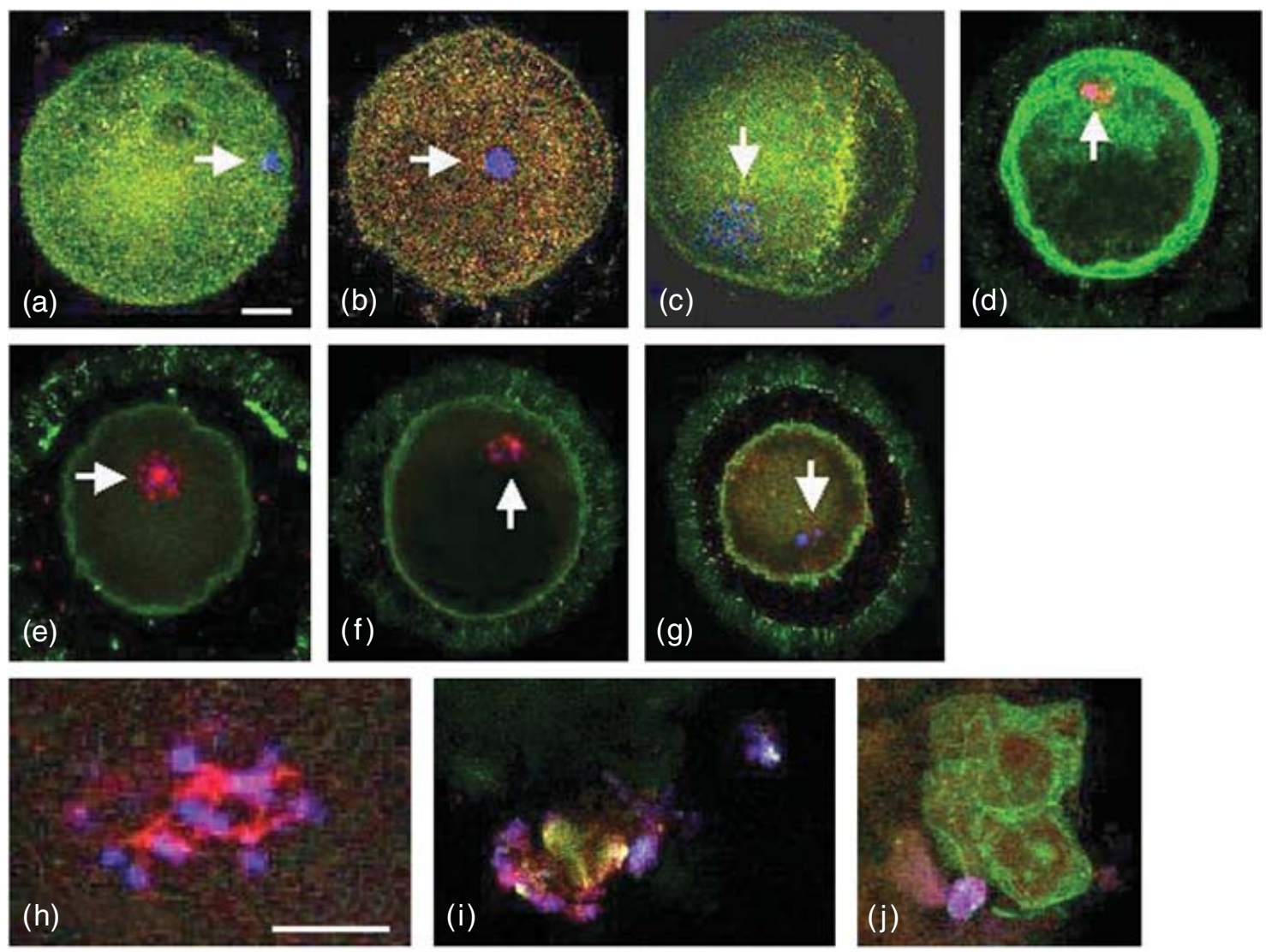

Fig. 2. Morphology of chromatin (blue), microtubules (red) and microfilaments (green) of developmentally blocked horse oocytes at first embryonic division after nuclear transfer. (a) Unchanged donor nucleus at the interphase stage; (b) swelling nucleus; (c) and (d) prometaphase stage; (e) metaphase stage; (f) and (g) anaphase stage (chromosomes separating); (h), (i) and (j): abnormalities of structure in the chromosomes and microtubular reorganization at the first embryonic division. Arrows indicate the position of the chromatin or microtubules. Scale bars represent $20 \mu \mathrm{m}$.

Table 3. State of the chromatin and microtubules in reconstructed horse oocytes developmentally blocked at the first embryonic division after nuclear transfer using fetal or adult fibroblast cells

\begin{tabular}{|c|c|c|c|c|c|c|c|}
\hline \multicolumn{2}{|c|}{ Donor cell } & \multirow[b]{2}{*}{$\begin{array}{l}\text { Number of } \\
\text { oocytes }\end{array}$} & \multicolumn{3}{|c|}{ Chromatin (\%)* } & \multicolumn{2}{|c|}{ Microtubules (\%) } \\
\hline Type & $\begin{array}{l}\text { Number of } \\
\text { passages }\end{array}$ & & Prometaphase & $\geqslant$ Metaphase & Other stages & $\begin{array}{c}\text { Associated } \\
\text { with chromatin }\end{array}$ & Other stages \\
\hline FFC & $3-5$ & 18 & 7 (39) & $4(22)$ & 7 (39) & $10(56)$ & $8(44)$ \\
\hline AFC & $3-5$ & 12 & $5(42)$ & $1(8)$ & $6(50)$ & $6(50)$ & $6(50)$ \\
\hline
\end{tabular}

*Interphase: decondensed chromatin enclosed within a nuclear membrane with the tubulin distributed throughout the cytoplasm and not into distinct microtubules.

Prometaphase: chromatin condensed and accompanied by distinct threads of microtubules, but not yet organized into a well-defined spindle. Chromosomes not aligned on to a metaphase plate.

$\geqslant$ Metaphase: developmental changes observed after prometaphase, basically with fragmentation or separation of the chromosomes and microtubule centres.

FFC: fetal fibroblast cells; AFC: adult fibroblast cells.

\section{Analysis of the organization of the first embryonic division in the developmentally blocked oocytes}

The organization of chromatin, microtubules and microfilaments in the reconstructed oocytes blocked in the first embryonic division is illustrated (Fig. 2) and summarized (Table 3). Overall, the microtubules in $56 \%$ of FFC and $50 \%$ of AFC reconstructed oocytes were associated with the chromatin of donor cells. However, most of these (including all those at interphase and 
prometaphase) could not form the whole mitotic spindle necessary to proceed to the next metaphase stage (FFC: $78 \%$; AFC: $92 \%$ ). Thus, $39 \%$ in the FFC group and $42 \%$ in the AFC group showed the prometaphase of the first embryonic division in which chromatin had condensed as a start to the formation of chromosomes with associated concentrated microtubules. In $22 \%$ of FFCconstructed oocytes and $8 \%$ of AFC-constructed oocytes the chromosomes were at metaphase or were beginning to separate, but could not complete the first embryonic division. Microfilaments had concentrated to form a rich domain surrounding the area of chromatin-microtubule complexes in the prometaphase-stage oocytes whereas they formed a network throughout the ooplasm in the oocytes blocked at other stages.

\section{Discussion}

The present study compared the competence of two types of cell (FFC and AFC) to undergo nuclear remodelling and the first embryonic division after nuclear transfer. Results showed average rates of cell fusion and nuclear remodelling of about $70-78 \%$ when using both fetal and adult fibroblasts, with no significant differences between the two types of cell in their ability to act as donor nuclei to reconstruct enucleated oocytes. This finding is similar to those in other domestic species used for nuclear transfer experiments, and it establishes that the nuclei of both fetal and adult horse fibroblasts have similar potential to induce remodelling in oocytes matured in vitro. Furthermore, after $28-30 \mathrm{~h}$ of culture after cell fusion, the average rates of embryonic cleavage to the two-cell stage in the reconstructed oocytes were again not different between those made with fetal versus adult fibroblasts ( $27 \%$ and $25 \%$, respectively).

However, when comparing these rates of first embryonic division in the reconstructed horse oocytes with those of other domestic species, large differences are evident, as $25-27 \%$ is only about half the rate achieved routinely in cattle (Kato et al., 2000), sheep (Campbell et al., 1996a; Wilmut et al., 1997), goats (Baguisi et al., 1999; Keefer et al., 2001) and pigs (Lai et al., 2001; Park et al., 2001). The remodelling of the donor cell nucleus and the first embryonic division in the reconstructed oocytes has been characterized in mice, rabbits and cattle, and this has indicated that the state of the cytoplasm in the recipient oocyte is a key factor in the production of cloned embryos and normal offspring (Campbell et al., 1993, 1996b; Cibelli et al., 1998: Kono, 1998; Robl, 1999; Shin et al., 2002). Co-culture of horse COCs with oviduct epithelial cells has improved cytoplasmic maturation to support fertilization and embryonic development better after intracytoplasmic sperm injection (Li et al., 2001b). Therefore, this study used the same in vitro culture system to provide the metaphase II oocytes used as recipient cytoplasts. In addition, induction of parthenogenesis showed that $79 \%$ of metaphase II oocytes that had matured under the same conditions used in nuclear transfer progressed to two-cell stage embryos. This result indicates the presence of different requirements for horse cytoplasmic competence in fertilization, parthenogenesis and nuclear remodelling. The molecular mechanisms involved in reprogramming donor nuclei after somatic cell nuclear transfer have not been fully elucidated. Thus, the question remains as to how best to provide more physiologically mature metaphase II oocytes from abattoir ovaries for horse nuclear transfer studies.

The number of donor cell passages is another significant factor when attempting to clone by nuclear transfer. Kubota et al. (2000) found no differences in the development of nuclear transfer embryos when using adult fibroblasts that ranged in passage numbers from five to 15 . In the present study, the rate of nuclear remodelling decreased significantly when using fetal fibroblasts of increasing passage number. During cell passage, both genetic and epigenetic alterations that might affect nuclear remodelling would be expected to accumulate in the cultured cells, and other possible disruptions to the regulation of imprinted genes could also be induced by repeated culture, thereby leading to perturbations in embryonic and fetal development (Walker et al., 1996; Wakayama et al., 1999). Furthermore, it would be sensible to try other types of cell obtained from different somatic tissues for use as cell donors in this species.

Successful cell division requires the formation of the metaphase spindle after DNA replication during the normal mitotic cell cycle. By confocal microscopic analysis of non-cleaved oocytes in the present study, it was possible to demonstrate that the microtubules in $78 \%$ of FFC-constructed oocytes, and in $92 \%$ of AFCconstructed oocytes, did not form a mitotic spindlelike structure and so were unable to progress to later stages of the first cell cycle. Furthermore, even the $22 \%$ of the FFC-constructed oocytes and $8 \%$ of the AFC-constructed oocytes in which the chromosomes were at the metaphase stage, or were beginning to separate, could not complete the first embryonic division due either to structural defects of the spindle, or the distribution of the chromosomes, or both. Tremoleda et al. (2001) reported that changes in the microtubules and the organization of the microfilaments during in vitro maturation of horse oocytes are similar to those seen in other species. Thus, it can be speculated that the underlying cause of the first embryonic division block in the reconstructed horse oocytes created by nuclear transfer may be a deficiency of the cytoplasmic transition factors in the recipient cytoplasm, such as those in the cell cyclin family and other cyclin-dependent factors, that are involved specially in the progression of the introduced donor nucleus from S-G2-prometaphase to metaphase. 
In addition, in contrast to the situation in mitotic cells, meiotic spindles in mammalian oocytes lack centrioles. Hence, the introduction of a foreign centrosome during somatic cell nuclear transfer results in the presence of the centrioles which play an indispensable role in reorganization of the first embryonic division in the reconstructed oocytes (Navara et al., 1994; Shin et al., 2002). Whether these factors are relevant to horse nuclear transfer remains to be clarified.

In summary, the present study investigated the rates of nuclear remodelling and two-cell embryonic development, and examined the reasons for the developmental block in progression to the two-cell stage in horse oocytes reconstructed using both fetal and adult fibroblasts that had undergone different numbers of passage in vitro. The findings indicate that fetal and adult fibroblasts that have undergone few passages (3-10) are equally suitable for use as nuclear donors. However, a marked improvement in the rate at which the reconstructed oocytes progress from the S-G2-prometaphase stage to beyond metaphase is needed before attempts to produce viable cloned embryos in this species are likely to be successful.

This study was supported by the Moller Charitable Trust, the Japan Racing Association and the Thoroughbred Breeders' Association. The authors are grateful to Potters Abattoir of Staplegrove, Somerset for kindly supplying the horse ovaries.

\section{References}

Albertini DF, Herman B and Sherline P (1984) In vivo and in vitro studies on the role of HMW-MAPs in taxol-induced microtuble bundling European Journal of Cell Biology 33 134-143

Baguisi A, Behboodi E, Melican DT et al. (1999) Production of goats by somatic cell nuclear transfer Nature Biotechnology 17 456-461

Campbell KHS, Ritchie WA and Wilmut I (1993) Nuclear-cytoplasmic interactions during the first cell cycle of nuclear transfer reconstructed bovine embryos: implications for deoxyribonucleic acid replication and development Biology of Reproduction 49 933-942

Campbell KHS, McWhir J, Ritchie WA and Wilmut I (1996a) Sheep cloned by nuclear transfer from a cultured cell line Nature 380 64-66

Campbell KHS, Loi P, Cappai P and Wilmut I (1996b) Cell cycle coordination in embryo cloning by nuclear transfer Reviews of Reproduction 1 40-46

Cibelli JB, Stice SL, Golueke PJ, Kane JJ, Jerry J, Blackwell C, Ponce de Leon FA and Robl JM (1998) Cloned transgenic calves produced from non-quiescent fetal fibroblasts Science $\mathbf{2 8 0} 1256-1258$

Hill JR, Winger QA, Long CR, Looney CR, Thompson JA and Westhusin ME (2000) Development rates of male bovine nuclear transfer embryos derived from adult and fetal cells Biology of Reproduction 62 11351140

Hinrichs K, Shin T, Love CC, Varner DD and Westhusin ME (2000) Comparison of bovine and equine oocytes as host cytoplasts for equine nuclear transfer. In Proceedings of 5th International Symposium on Equine Embryo Transfer Havemeyer Foundation Monograph Series No. 3 p 26

Kato Y, Tani T, Sotomaru Y, Kurokawa K, Kato J, Doguchi H, Yasue H and Tsunoda $Y$ (1998) Eight calves cloned from somatic cells of a single adult Science 282 2095-2098

Kato Y, Tani T and Tsunoda Y (2000) Cloning of calves from various somatic cell types of male and female adult, newborn and fetal cows Journal of Reproduction and Fertility 120 231-237

Keefer CL, Baldassarre H, Keyston R et al. (2001) Generation of dwarf goat (Capra hircus) clones following nuclear transfer with transfected and nontransfected fetal fibroblasts and in vitro-matured oocytes Biology of Reproduction 64 849-856

Kono T (1998) Influence of epigenetic changes during oocyte growth on nuclear reprogramming after nuclear transfer Reproduction, Fertility and Development 10 593-598

Kubota C, Yamakuchi H, Todoroki J, Mizoshita K, Tabara N, Barber M and Yang X (2000) Six cloned calves produced from adult fibroblast cells after long-term culture Proceedings National Academy of Sciences USA 97 990-995

Lai L, Tao T, Machaty Z, Kuhholzer B, Sun QY, Park KW, Day BN and Prather RS (2001) Feasibility of producing porcine nuclear transfer embryos by using G2/M-stage fetal fibroblasts as donors Biology of Reproduction 65 1558-1564

Li X, Morris LHA and Allen WR (2000a) Chromatin reprogramming in enucleated horse oocytes injected with cumulus cell nuclei Journal of Reproduction and Fertility Abstract Series $\mathbf{2 5}$ Abstract 77

Li X, Morris LHA and Allen WR (2000b) Effects of different activation treatments on fertilization of horse oocytes by ICSI Journal of Reproduction and Fertility 119 253-260

Li X, Morris LHA and Allen WR (2001a) Studies on the fusion and activation conditions required for nuclear transfer to horse oocytes Journal of Reproduction and Fertility Abstract Series $\mathbf{2 7}$ Abstract 22

Li X, Morris LHA and Allen WR (2001b) The influence of co-culture during maturation on the developmental potential of equine oocytes fertilized by intracytoplasmic sperm injection (ICSI) Reproduction 121 925932

Li X, Morris LHA and Allen WR (2002) In vitro development of horse oocytes reconstructed with the nuclei of fetal and adult cells Biology of Reproduction 66 1288-1292

Navara CS, First NL and Schatten G (1994) Microtubule organization in the cow during fertilization, polyspermy, parthenogenesis, and nuclear transfer: the role of the sperm aster Development Biology 16229 40

Park KW, Lai L, Cheong HT, Im GS, Sun QY, Wu G, Day BN and Prather RS (2001) Developmental potential of porcine nuclear transfer embryos derived from transgenic fetal fibroblasts infected with the gene for the green fluorescent protein: comparison of different fusion/activation conditions Biology of Reproduction 65 1681-1685

Reggio BC, Cochran RA, Guitreau A, Carter JA, Denniston RS and Godke RA (2000) Transvaginal follicle aspiration and electrofusion of reconstructed equine oocytes. In Proceedings of 5th International Symposium on Equine Embryo Transfer Havemeyer Foundation Monograph Series No. 3 p 45

Reggio BC, James AN, Green HL, Gavin WG, Behboodi E, Echelard Y and Godke RA (2001) Cloned transgenic offspring resulting from somatic cell nuclear transfer in the goat: oocytes derived from both folliclestimulating hormone-stimulated and nonstimulated abattoir-derived ovaries Biology of Reproduction 65 1528-1533

Robl JM (1999) Development and application of technology for large scale cloning of cattle Theriogenology 51 499-508

Roh S, Shim H, Hwang W and Yoon J (2000) In vitro development of green fluorescent protein (GFP) transgenic bovine embryos after nuclear tansfer using different cell cycles and passages of fetal fibroblasts Reproduction, Fertility and Development 12 1-6

Shin MR, Park SW, Shim H and Kim NH (2002) Nuclear and microtubule reorganization in nuclear-transferred bovine embryos Molecular Reproduction and Development 62 74-82

Simerly C and Schatten H (1993) Techniques for localization of specific molecules in oocytes and embryos. In Methods in Enzymology pp 516552 Eds PM Wassarman and ML DePamphilis. Academic Press, New York

Tremoleda JL, Schoevers EJ, Stout TAE, Colenbrander B and Bevers MM (2001) Organisation of the cytoskeleton during in vitro maturation of horse oocytes Molecular Reproduction and Development 60260 269 
Wakayama T, Rodriguez I, Perry ACF, Yanagimachi $\mathbf{R}$ and Mombaerts $\mathbf{P}$ (1999) Mice cloned from embryonic stem cells Proceedings National Academy of Sciences USA 96 14 984-14989

Walker SK, Hartwich KM and Seamark RF (1996) The production of unusually large offspring following embryo manipulation: concepts and challenges Theriogenology 45 111-120

Wells DN, Misica PM and Tervit R (1999) Production of cloned calves following nuclear transfer with cultured adult mural granulosa cells Biology of Reproduction 60 996-1005

Westhusin ME, Long CR, Shin T, Hill JR, Looney CR, Pryor JH and Piedrahita
JA (2001) Cloning to reproduce desired genotypes Theriogenology 55 35-49

Wilmut I, Schnieke AE, McWhir J, Kind AJ and Campbell KHS (1997) Viable offspring from fetal and adult mammalian cells Nature 385 810-813

Received 7 August 2002.

First decision 7 November 2002.

Revised manuscript received 20 November 2002.

Accepted 13 January 2003. 